\title{
Internationalism and Commitment at the Kitchen Table
}

\author{
Ruth Fletcher $^{1} \cdot$ Julie McCandless $^{2} \cdot$ Yvette Russell $^{3}$. \\ Dania Thomas ${ }^{4}$
}

\begin{abstract}
The contributors to this issue focus on legal internationalism (Peroni 2016; Turan 2016), including hybrid mixes with nationalist forms (Sankey 2016). They have provoked us as editors to think more about these sites and forms of engagement. Sankey shows how civic participation in the ECCC has played a key role in surfacing the gendered harms of separation and starvation. Turan highlights the problems with ICC exclusion of the experience of men and boys from sexual violence. Peroni expresses her hesitations over the Istanbul Convention given an association between assumed vulnerability and migrant women, while admiring its uncoupling of violence and culture. Cruz's interview with Wendy Brown (2016) contextualizes and expands on these themes as they consider, with other participants, the future of feminist theory in the context of neo-liberal capturing of rights and legal space. Thinking more about internationalism and commitment in this context also helps us hold a mirror up to ourselves as we reflect more critically on our own naming of FLS as an 'international' journal. Together these contributions, and the reviews of new work, play a role in fleshing out an editorial commitment to enacting the journal as a living thing that 'hangs together somehow' (Mol 2002) even as it is known differently in different places.
\end{abstract}

You just have to write and put your effort into building the movement and the alliances that you want, rather than trying to imagine that somehow a theoretical precept will have political purity (Brown in Cruz and Brown 2016).

$\triangle$ Ruth Fletcher

r.fletcher@qmul.ac.uk

1 Queen Mary, University of London, London, UK

2 London School of Economics, London, UK

3 Bristol University, Bristol, UK

4 University of Glasgow, Glasgow, UK 
In these days of preoccupation with global movement and transnational flow, internationalism seems a dated, even jaded, term. We foreground it here in part as a gesture of critical feminist recovery. ${ }^{1}$ What kind of contributions to feminist legal internationalism do we want to hold on to as touchstones? Whose work steadies us on our way and encourages us in new directions and interesting detours? Even if there might be aspects we would let drop away, or examples we wish to remould. Our contributors in this issue focus on legal internationalism (Peroni 2016; Turan 2016), sometimes in hybrid mixes with nationalist forms (Sankey 2016). They have provoked us as editors to think more about these sites and forms of engagement.

Thinking more about internationalism also helps us hold a mirror up to ourselves as we reflect on our own naming of FLS as an 'international' journal. As a feminist collective occupying the space of an editorial board, we often come back to the question: What does it mean to be an international journal these days with editorial board members based at a range of UK universities, a commercial publisher based in the Netherlands, production located in India, and a network of feminist legal advisers scattered around the globe? With FLaK, ${ }^{2}$ we want to claim some time and space to work this through a little more (Fletcher 2015). We have invited a mixed group of feminist thinkers to join us, thinkers from Drama and Media (Weaver and Harvie 2015; Kember 2014) as well as from critical socio-legal studies and legal humanities; and from the worlds of activism, civil society, art and museums, as well as of academia. ${ }^{3} \mathrm{We}$ are asking them to help us enact a kitchen table that will pull us out of our comfort zone as we think about multi-dimensional methods of working the senses, objects and techniques of legality alongside questions of craft, evidence and text. And we will consider how best to stop ourselves from filling space that might be better occupied by others. No doubt we will make a bit of a mess along the way. But we are committed to trying, to enacting the journal as a thing that 'hangs together somehow' (Mol 2002) even as it is known differently in different places, and to fleshing out some of the spaces it provides.

The three original articles in this issue participate in feminist conversations about the nature, scope and meaning of legal interventions in the international realm. They build on important critiques made in this journal (e.g. Buss 2009) and elsewhere about a disproportionate and exclusionary emphasis on sexualized violence. Sankey

\footnotetext{
1 For a thoughtful consideration of 'the question of recovery' see Helton et al. (2015), who locate the starting point of their special issue as "the generative tension between recovery as an imperative that is fundamental to historical writing and research-an imperative infused with political urgency by generations of scholar-activists - and the impossibility of recovery when engaged with archives whose very assembly and organization occlude certain historical subjects."

${ }^{2}$ For more information see http://www.law.qmul.ac.uk/events/items/167540.html

3 As well as Editorial Board members (see the membership list here http://www.springer.com/law/ international/journal/10691?detailsPage=editorialBoard), participants will include: Annie Fletcher (Van Abbemuseum), Carys Craig (Osgoode), Davina Cooper (Kent), Denise Ferreira da Silva (University of British Columbia), Doris Buss (Carleton), Emilie Cloatre (Kent), Feminist Fightback, Jane Krishnadas (CLOCK, Keele), Karin Van Marle (Pretoria), Kristin Bergtora Sandvik (Peace Research Institute, Oslo), Lois Weaver (QMUL), Máiréad Enright (Kent), Marie Andrée Jacob (Keele), Mel Evans (Liberate Tate), Moira Dustin (Equality and Diversity Forum Research Network), Rosemary Hunter (QMUL), Samia Bano (SOAS), Sarah Kember (Goldsmiths), Sonia Lawrence (Osgoode), Speaking of I.M.E.L.D.A. and Stacy Douglas (Carleton).
} 
turns a feminist critical gaze on the hybrid tribunal of the Extraordinary Chambers in the Courts of Cambodia (2016), and the investigation of the violence of forced population movements 40 years after the establishment of the Khmer Rouge regime. She recognises the achievements of the Tribunal and goes on to address its shortcomings in what might be termed the mode of 'critical friend'. Her analysis draws on the work of feminist scholars such as Conaghan, Ní Aoláin and West in capturing the conception of harm that animates her contribution. Noting a relative lack of gender-related expertise at the Court and the Court's innovative system of civil party participation, Sankey draws out the significance of civil party participation in challenging gaps in gender awareness and in recognizing the harms of familial separation and starvation. Her evocative account of the 'surfacing' of evidence of these harms through oral testimony reaches out to those interested in more general questions of the relationship between craft, text and evidence in legal forms.

Turan's article, 'Manhood Deprived' (2016), focuses the critical gaze on a slightly different dimension of international legal efforts to address sexual violence or what she terms the "internationalization of sexual violence crimes". She draws on feminist critiques which have tracked two transitions, one which has contributed to displacing the category of honour with a criminal framework (e.g. Gill 2013; Razack 2004) and a second which understands violence less as a side effect of conflict, and more as a weapon of conflict (e.g. Buss 2009). She considers the failure of the International Criminal Court (ICC) to recognise forced circumcision and penile mutilation as sexual violence, in the Kenyan case. The ICC identified the lack of a sexual element and the ethnic character of the prejudice as the key reasons why these actions were not sexual violence. Turan points out that this raises a number of related concerns. It suppresses "alternative and subordinated voices" and fails to recognise and confront gendered and sexualized harms which men and boys suffer. Interestingly she argues that it does so in a way which consolidates the gendered femininity of victimhood and undermines the established recognition of links between ethnicity and sexuality.

Peroni picks up the engagement with legal internationalism in two important ways (2016). First she provides a close reading of a relatively new international legal instrument in the struggle to combat violence against women: the Council of Europe's Istanbul Convention. ${ }^{4}$ Second she brings the work of feminist scholars such as Razack, Kapur, Otto and Dustin to bear on critiquing that Convention. She finds that the Convention has avoided the trap of depicting certain kinds of violence as if they are culturally distinct, and has avoided the use of separate frames for different instances of violence against women. But she is concerned that the Convention may end up falling back on assumptions about the vulnerability of migrant, refugee and asylum-seeker women, and contribute to their stigmatization. In this way, Peroni articulates a method of feminist legal critique which shows us how this new recipe for legal action has responded to critical findings about legal

\footnotetext{
4 The Council of Europe Convention on Preventing and Combating Violence against Women and Domestic Violence, see further: http://www.coe.int/en/web/istanbul-convention/home Accessed 1 April 2016.
} 
interventions on violence against women, and draws our attention to the potential for shortcomings. It remains to be seen how actual practices of implementation, interpretation, and investigation will give life to the text itself.

Cruz's interview and the multi-participant discussion with Wendy Brown address this question of internationalism, among others (2016). Interestingly, Brown reminds us of the role that some kinds of powerful feminism have played in consolidating exclusionary and patronizing forms of internationalism: "Barbara Bush became one of our most important feminist spokespersons in the early 2000s. That feminism had of course a classic Christian missionary white dimension, it had an imperial dimension". For Brown this kind of imperialist rescue feminism is more concerning than the governmental feminism that tends to be associated with MacKinnon and certain kinds of feminist mainstream interventions, particularly in the wake of Halley's characterization (2006). With Brown, and other participants, we would rather remember other forms and aspects of feminist legal internationalism, particularly those which are critical, grounded, and committed. As Brown says, even if hope might drain more than it sustains, commitment "to try to either stave off the dark or bring about a better world" keeps many forms of critical engagement alive.

The reviews in this issue sustain feminist legal inquiry by providing critical considerations of different types of scholarly engagement. Coysh (2016) considers Al-Sharmi's rich edited collection on feminist activism, women's rights and legal reform across a range of jurisdictions, including Palestine, Egypt, Yemen, Bangladesh, Iran, Morocco, Brazil and Ghana. Greasley applies the lens of analytical philosophy in her review of Cook, Erdman and Dickens's Abortion Law in Transnational Perspective (2016), a collection which draws out the significance of subtle legal changes and challenges across a wide range of contexts. Geerts draws out the feminist significance of Auestad's engagement with object-relations theory as it considers the situatedness of the subject through her notion of "otherinterpreted-and-interpreting" beings (2016). Lloyd reviews Seshadri's contribution to the Posthumanities in HumAnimal (2016) as it engages with Derridean concepts to "reclaim silence as an affirmative action". Kyneswood analyses the results of the Australian Feminist Judgments project, which include re-imaginings by indigenous judges on the treatment of Aboriginal peoples (2016). In a novel contribution to our reviews section, Seabourne, a legal historian, considers the film Suffragette and its use of fiction to explore women's legal history and this particular feminist struggle (2016).

As we at FLS look around us at the imaginative feminisms that are demanding attention and action, we see how their commitments to knowing and changing the world are fleshing out critical understanding of law's multi-dimensionality. When the FocusE15 mums take to the streets with children in prams, occupy council housing and staff their Stratford stall every week (Watt 2016; Taylor 2015), they are making Brown's 'femina domestica' visible and audible. In her interview with Cruz, Brown talks about how she is "working at a theoretical level to think about where, what I call the figure of femina domestica, the invisible counterpart to homo economicus, still circles around and under, in an invisible way, the figure of human capital that's at the heart of neoliberalism." Perhaps FocusE15 are re-directing 
femina domestica's time and energy in inspirational ways? When SpeakingOfImelda turn 'dirty work' into knickers of knowing protest, they show us the potential for transforming legal harms, recovering resistance and generating joyful encounters (2015). With Brown, FocusE15, SpeakingOfImelda and many other critical, knowing feminisms and social justice campaigns, we want to imagine a kitchen table for $F L S$ which sees life in legal food, takes pleasure in bringing people together and fills faultlines with evocative scents and sounds.

\section{References}

Buss, Doris. 2009. Rethinking rape as a weapon of war. Feminist Legal Studies 17(2): 145-163. doi:10. 1007/s10691-009-9118-5.

Coysh, Joanne. 2016. Review of Mulki Al-Sharmani (ed.) Feminist activism, women's rights and legal reform. Feminist Legal Studies 24(1). doi:10.1007/s10691-015-9305-5.

Cruz, Katie, and Wendy Brown. 2016. Feminism, law, and neoliberalism: An interview and discussion with Wendy Brown. Feminist Legal Studies 24(1). doi:10.1007/s10691-016-9314-z.

Fletcher, Ruth. 2015. FLaK: Mixing feminism, legality and knowledge. Feminist Legal Studies 23(3): 241-252. doi:10.1007/s10691-015-9306-4.

Geerts, Evelien. 2016. Review of Lene Auestad: Respect, Plurality, and Prejudice: A psychoanalytical and philosophical enquiry into the dynamics of social exclusion and discrimination. Feminist Legal Studies 24(1). doi:10.1007/s10691-015-9298-0.

Gill, Aisha. 2013. Feminist reflections on researching so-called 'honour' killings. Feminist Legal Studies 21(3): 241-261. doi:10.1007/s10691-013-9249-6.

Greasley, Kate. 2016. Rebecca J. Cook, Joanna N. Erdman, and Bernard M. Dickens (eds): Abortion law in transnational perspective: Cases and controversies. Feminist Legal Studies 24(1). doi:10.1007/ s10691-016-9312-1.

Halley, Janet. 2006. Split decisions: How and why to take a break from feminism. Princeton: Princeton University Press.

Helton, Laura, Justin Leroy, Max A. Mischler, Samantha Seeley, and Shauna Sweeney. 2015. The question of recovery: Slavery, freedom and the archive. Social Text 33(4 125): 1-18. http:// socialtext.dukejournals.org/content/33/4_125/1.full.pdf+html.

Kember, Sarah. 2014. Why write? Feminism, publishing and the politics of communication. New Formations: A Journal of Theory/Culture/Politics 84: 99-116. doi:10.3898/NEWF.83.06.2014.

Kyneswood, Natalie. 2016. Heather Douglas, Francesca Bartlett, Trish Luker and Rosemary Hunter (eds): Australian feminist judgments: Righting and rewriting law. Feminist Legal Studies 24(1). doi:10. 1007/s10691-016-9311-2.

Lloyd, Chris. 2016. Kalpana Rahita Seshadri HumAnimal: Race, law, language. Feminist Legal Studies 24(1). doi:10.1007/s10691-015-9297-1.

Mol, Annemarie. 2002. The Body Multiple. Durham: Duke University Press.

Peroni, Lourdes. 2016. Violence against migrant women: The Istanbul Convention through a postcolonial feminist lens. Feminist Legal Studies 24(1). doi:10.1007/s10691-016-9316-x.

Razack, Sherene. 2004. Imperilled Muslim women, dangerous Muslim men and civilised Europeans: Legal and social responses to forced marriages. Feminist Legal Studies 12(2): 129-174. http://link. springer.com/article/10.1023\%2FB\%3AFEST.0000043305.66172.92.

Sankey, Diana. 2016. Recognition of gendered experiences of harm at the extraordinary chambers in the courts of Cambodia: The Promise and the Pitfalls. Feminist Legal Studies 24(1). doi:10.1007/ s10691-016-9309-9.

Seabourne, Gwen. 2016. Deeds, words and drama: A review of the film Suffragette (2015). Feminist Legal Studies 24(1). doi:10.1007/s10691-015-9307-3.

Speaking of I.M.E.L.D.A. 2015. Dirty work still to be done: Retrieving and activating feminist acts of resistance. In Celebrating Margaretta Darcy's Theatrical Activism. Contemporary Theatre Review 
Interventions (July). http://www.contemporarytheatrereview.org/2015/margaretta-darcy/. Accessed 30 March 2016.

Taylor, Ayesha. 2015. FocusE15, women and the housing crisis. Presentation to GMB Young London and GMB London Sister's event on housing and women. 8 September. https://www.youtube.com/ watch?v=JhWSIKcAeNc. Accessed 30 March 2016.

Turan, Gözde. 2016. Manhood deprived and (re)constructed during conflicts and international prosecutions: The curious case of the Prosecutor v. Uhuru Muigai Kenyatta et al. Feminist Legal Studies 24(1). doi:10.1007/s10691-016-9313-0.

Watt, Paul. 2016. A nomadic war machine in the metropolis: En/countering London's 21st century crisis with FocusE15. City 20(2): 297-320. doi:10.1080/13604813.2016.1153919.

Weaver, Lois, and Jen Harvie (eds.). 2015. The only way home is through the show: Performance work of Lois Weaver. London: Live Art Development Agency and Intellect Books. 